\title{
An Investigation on Special Talent Exams in the Division of Art Teaching
}

\author{
Selma Taşkesen \\ Correspondence: Erzincan Binali Yıldırım University, Education Faculty, Turkey.
}

Received: October 8, 2019

doi:10.11114/jets.v7i10S.4554
Accepted: October 27, 2019 Online Published: October 28, 2019

URL: https://doi.org/10.11114/jets.v7i10S.4554

\begin{abstract}
In this research, it is aimed to investigate the application, implementation and evaluation processes of the exam held by the Institutions of Higher Education in selecting students to the art teaching departments, which educate students with special talents in Turkey. This research is appropriate for the descriptive survey model. The document survey technique was applied in the research. The universe of the research consists of the Art Teaching Divisions, which take students with special talent exams in the 2018-2019 academic year. In the research, the sample was not determined to reach the whole universe. According to the findings of the research, the application conditions, implementation and evaluation of the special talent exams applied by the Institutions of Higher Education were found to have different and similar sides. As a result, although the application conditions, implementation and evaluation of the exams are similar, it has been concluded that the centralization of special talent exams will provide coherence.
\end{abstract}

Keywords: art training, art education, visual arts, special talent exam

\section{Introduction}

Art is a concept that has existed in human life and what it means has always been discussed. We can define the art as one's expressing his/her emotions, thoughts and desires by combining them with the richness of imagination. In another definition, Tepecik (2002) defined art as, "man's talent to create a form". According to Artut (2004), "art is a necessity of human nature and one of the most important dimensions and elements of social life." Art, an infinite and universal language that can be defined in many ways, has also been included in the education system as it has been involved in daily life and can be taught. San (1983) refers his opinion related to the art training practice at schools, as, "with art lessons existing in the education system, the men, who have transformed into a robot and become mechanical by the era, will eliminate the danger". Ozsoy (2007) referred that the art training important by claiming that "visual art training is one of the most important education fields even in 21 st century considering it is the information and communication age as it was in the previous century, and for its nature beginning from pre-school to university and with its characteristics that can last a lifetime from cradle to grave." Art training is given by the higher education institutions to provide professional in Turkey including at all the levels of education in different types. Art education given in undergraduate level is peculiar to the educational institutions that students prefer following their talents. Individuals with special talents can have a profession by studying in these educational institutions. Special talent is an individual's ability to demonstrate high ability in one or more areas that are culturally valuable (Pfeiffer, 2003). In another definition, Marland Report (1972) referred the giftedness as extraordinary high performance. Besides, six different fields of giftedness were mentioned. In the report, as the fields s/he is talented; general intellectual skill, high academic achievement, productive and creative thinking, leadership, skill in arts that require visual and performance and psychomotor skill. Children, who show an extraordinary skill at least one of these fields, are described as gifted. Following the wish of an individual, who owns any of these qualifications; it is possible to get an education. However, different view exists related to this topic. "While some authorities defend the necessity of benefiting from enriched educational environments for all students who fall within these criteria by keeping the diagnostic criteria broad, others advocate educating students who are truly exceptional and unique in differentiated curricula" (Karadag, 2016). According to the conditions and their preferences, talented students are selected to the higher education institutions; besides, central placement, with Special Talent exams, which date back to 1975 . These exams aim to select students to the higher education institutions determining those who have special talents in the fields such as physical education, art and music (Gurbuzturk \& Kıncal, 2018). Special talent exams are applied to select students to the relevant departments, main art and divisions, which require special talents such as Art and Sports Training Departments of the Faculties of Education, Conservatory Departments in Faculties of Fine Arts, Faculties of Art and Design. As there is few faculties, which select their students with a system based on Special Talent Exam, selecting students to these faculties is difficult. In Turkey, the Assessment Selection and 
Placement Centre (ASPC) is the institution that conducts the Higher Education Institutions Examination (HIE), which determines the selection and placement of the students to be admitted to Higher Education Institutions. The ASPC describes the application evaluation principles for the institutions of Higher education, which select students with Special Talent Exam in the manual.

According to the HIE (2019) manual, the following three scores are used to calculate the placement-based score, multiplied by certain weights, and summed.

a) STES Standard Score (STES-SS): The STES Standard Score (STES-SS) is the score emerging as a result of weighting the Special Talent Exam Score (STES) with a definite formula.

b) High School Achievement Score

c) 2019-Basic Proficiency Test Score (BPT-S)

For the Special Talent Exam Score (STES) to enter weighting, these scores must be converted to standard scores. To convert the STES scores to the standard score, first the mean and standard deviation of the STES distribution will be calculated then, the STES standard Score is calculated for each students using the following formula.

The Special Talent Exam Score (STES) is one of the most applied weighted scores in calculating the placement score. The relevant departments of faculties of Higher education institutions determine the Application Requirements for the Exams that constitute Special Talent Exam Scores, how many steps it will include, exam types, topics, techniques and exam duration. Determining similarities and differences in application conditions, questions, implementation of these exams prepared, implemented and evaluated by the Higher education institutions, as the measurement tool constitutes the main problem of the research. As a result of the literature review, it is noticed that studies related to this topic have been conducted (Kavuran, 2003-2004; Altınkurt, 2006; Askın Kumova \& Demirbatır, 2012; Kirpik \& Sirin, 2012; Arapgirligoglu \& Tankız, 2013; Sager, Zahal, Ozhan. \& Gurpınar, 2015; Ucan, 2015; Gurbuzturk \& Kincal, 2018; Erol, 2016). With similar studies, in this present study, which is believed to contribute to the relevant literature, it is aimed to compare the application, implementation and evaluation steps of exam applied by the Institutions of Higher Education in selecting students to the art teaching programs which require special talents in Turkey.

With this purpose, the following research questions were asked.

1. What is the general information (periods, quotas) related to the Special Talent Exams for Art Teaching Divisions of Fine Arts Departments of Education Faculties?

2. What are the application conditions of the Special Talent Exams for Art Teaching Divisions of Fine Arts Departments of Education Faculties?

3. What are the steps of the Special Talent Exams for Art Teaching Divisions of Fine Arts Departments of Education Faculties?

4. What criteria are used in the evaluation of the Special Talent Exams for Art Teaching Divisions of Fine Arts Departments of Education Faculties?

\section{Method}

\subsection{Research Pattern}

This research, which aims to compare the Special Talent Exams for Art Teaching Divisions of Fine Arts Departments of Education Faculties in Turkey in the 2018-2019 educational year, is appropriate to the descriptive survey model. The survey model aims to describe an existing state as it is. The subject, individual or object, are tried to be defined as their conditions. There is no attempt to change or influence them in any way. What is important is to observe and reveal what you want to know (Karasar, 2003). The document survey technique was applied in the research. Collecting data by examining existing records and documents are called documentary scanning (Madge, 1965). Duverger (1973) calls this method as "document observation".

\subsection{Universe and Sample}

The research universe consists of 34 Divisions of Art Teaching, which selected their students with Special Talent Exam in the 2018-2019 educational year. The reason why the data of the universe related to 2018-2019 were used in the research was the 300000 success ranking condition that the ASPC had planned to implement for the application of the special talent exams in 2018 and then postponed to 2019. In the research, the sample was not determined to reach the whole universe.

The distribution of access the manual status for the Special Talent Exam of the Divisions of Art Teaching in Turkey in the 2018-2019 educational year is presented in Table 1. 
Table 1. The distribution of the manual access status for the Special Talent Exam of the Divisions of Art Teaching

\begin{tabular}{ll}
\hline Access Status & Special Talent Exam Manual \\
\hline Accessible & 23 \\
\hline Inaccessible & 11 \\
\hline Total & 34
\end{tabular}

\subsection{Data Collection Tools}

In the research by investigating the written- pressed and electronic resources to collect data, information was reached related to the Higher Education Institutions Exam (HIE) and the special Talent Exams. The investigation was limited to the resources of 2018 due to the 300000 success rankings that ASPC intended to put into practice for the education faculties and stated that it will also be applied for the departments of faculties of education that take students through special talent exam. In the research as the data collection tool, written-printed and electronic resources such as 2018 The Institutions of Higher Education Exam (HIE) Manual, Higher Education Programs and Quotas Manual (ASPC, 2018), special talent exams of universities.

\subsection{Analysis of Data}

The information gathered from the reviewed documents were analysed considering the changes in transition exam to the higher education in 2018, recommended success rankings and the Special Talent Exam requirements and implementation, evaluation steps. Data, gathered from the manuals of the Institutions of Higher Education, were analysed with descriptive analysis.

\section{Findings and Comments}

3.1 What Is the General Information (Periods, Quotas) Related to the Special Talent Exams for Art Teaching Divisions of Fine Arts Departments of Education Faculties?

General information (periods, quotas) related to the Special Talent Exams for Art Teaching Divisions of Fine Arts Departments of Education Faculties is shown in Table 2. 
Table 2. 2018 HIE Art Teaching Programs and Quotas

\begin{tabular}{|c|c|c|c|c|c|c|}
\hline & Universities & quotas & $\begin{array}{l}\text { Exam } \\
\text { Pre-Reg } \\
\text { Dates }\end{array}$ & & Exam Dates & Appl. Style \\
\hline 1 & Agri İbrahim Cecen U. & 50 & $\begin{array}{l}13-17 \text { th } \\
2018\end{array}$ & August & $\begin{array}{l}\text { 27th } \text { August } \\
2018\end{array}$ & Online Pre-registration \\
\hline 2 & Aksaray U. & 45 & Not reac & ned & & \\
\hline 3 & Anadolu U. & 55 & $\begin{array}{l}6-10 \text { th } \\
2018\end{array}$ & August & $\begin{array}{l}\text { 28th August } \\
2018\end{array}$ & Online Pre-registration \\
\hline 4 & Ataturk U. & 45 & $\begin{array}{l}1-8 \text { th } \\
2018\end{array}$ & August & $\begin{array}{l}\text { 15th August } \\
2018\end{array}$ & $\begin{array}{l}\text { Online+Personally } \\
\text { Pre-registration }\end{array}$ \\
\hline 5 & Aydin Adnan Menderes U. & 50 & $\begin{array}{l}6-10 \text { th } \\
2018\end{array}$ & August & $\begin{array}{l}\text { 13-17th } \\
\text { August } 2018\end{array}$ & $\begin{array}{l}\text { Personally } \\
\text { Pre-registration }\end{array}$ \\
\hline 6 & Bartin University & 30 & $\begin{array}{l}3-17 \text { th } \\
2018\end{array}$ & August & $\begin{array}{l}\text { 4-5th Sept. } \\
2018\end{array}$ & Online Pre-registration \\
\hline 7 & Bolu Abant İzzet Baysal U. & 40 & Not reac & ned & & \\
\hline 8 & Burdur Mehmet Akif Ersoy U. & 50 & Not reac & ned & & \\
\hline 9 & Bursa Uludag U. & 50 & $\begin{array}{l}3-8 \text { th } \\
2018\end{array}$ & August & $\begin{array}{l}\text { 13-15th } \\
\text { August } 2018\end{array}$ & Online Pre-registration \\
\hline 10 & Canakkale Onsekiz Mart U. & 35 & $\begin{array}{l}\text { 6-10th } \\
2018\end{array}$ & August & $\begin{array}{l}4-5 \text { th Sept. } \\
2018\end{array}$ & $\begin{array}{l}\text { Online+Personally } \\
\text { Pre-registration }\end{array}$ \\
\hline 11 & Cukurova U. & 45 & $\begin{array}{l}\text { 13-14-1 } \\
\text { August }\end{array}$ & $\begin{array}{l}-16 \text { th } \\
018\end{array}$ & $\begin{array}{l}\text { 29th } \text { August } \\
2018\end{array}$ & $\begin{array}{l}\text { Personally } \\
\text { Pre-registration }\end{array}$ \\
\hline 12 & Dicle U. & 50 & Not reac & ned & & \\
\hline 13 & Dokuz Eylul U. & 60 & Not reac & ned & & \\
\hline 14 & Ege U. & 30 & $\begin{array}{l}\text { 13-14-1 } \\
\text { August }\end{array}$ & $\begin{array}{l}\text { th } \\
018\end{array}$ & $\begin{array}{l}\text { 27-28-29th } \\
\text { August } 2018\end{array}$ & $\begin{array}{l}\text { Personally } \\
\text { Pre-registration }\end{array}$ \\
\hline 15 & Erzincan Binali Yildirim U. & 45 & $\begin{array}{l}31 \text { st } \\
\text { August }\end{array}$ & $\begin{array}{l}\text { July-5th } \\
018\end{array}$ & $\begin{array}{l}\text { 8th } \\
2018\end{array}$ & $\begin{array}{l}\text { Online+Personally } \\
\text { Pre-registration }\end{array}$ \\
\hline 16 & Firat U. & 45 & $\begin{array}{l}3-4-5 \text { th } \\
2018\end{array}$ & Sept. & $\begin{array}{l}\text { 6-7th } \quad \text { Sept. } \\
2018\end{array}$ & $\begin{array}{l}\text { Pre-registration in Person } \\
\text { and by Post }\end{array}$ \\
\hline 17 & Gazi U. & 70 & $\begin{array}{l}17-31 s t \\
2018\end{array}$ & August & 5th Sept.2018 & \\
\hline 18 & Giresun U. & 30 & Not reac & ned & & \\
\hline 19 & Harran U. & 50 & $\begin{array}{l}\text { 13-17th } \\
2018\end{array}$ & August & $\begin{array}{l}\text { 4-5th } \quad \text { Sept. } \\
2018\end{array}$ & Online Pre-registration \\
\hline 20 & Hatay Mustafa Kemal U. & 40 & $\begin{array}{l}\text { 6-10th } \\
2018\end{array}$ & August & $\begin{array}{l}\text { 14-16th } \\
\text { August } 2018\end{array}$ & $\begin{array}{l}\text { Online+Personally } \\
\text { Pre-registration }\end{array}$ \\
\hline 21 & İnonu U. & 50 & $\begin{array}{l}\text { 17th A } \\
\text { 1st Sept. }\end{array}$ & $\begin{array}{l}\text { Igust, - } \\
2018\end{array}$ & $\begin{array}{l}\text { 6-7th Sept. } \\
2018\end{array}$ & Online Pre-registration \\
\hline 22 & Kastamonu U. & 40 & Not reac & & & \\
\hline 23 & Marmara University U. & 100 & Not reac & & & \\
\hline 24 & Mugla Sitki Kocman U. & 40 & $\begin{array}{l}31 \mathrm{st} \mathrm{Ju} \\
\text { August }\end{array}$ & $\begin{array}{l}\text { ly- 9th } \\
018\end{array}$ & $\begin{array}{l}\text { 14-15th } \\
\text { August } 2018\end{array}$ & Online Pre-registration \\
\hline 25 & Necmettin Erbakan U. & 45 & Not reac & ned & & \\
\hline 26 & Nigde Omer Halisdemir U. & 50 & $\begin{array}{l}\text { 6-10th } \\
2018\end{array}$ & August & $\begin{array}{l}\text { 13th August } \\
2018\end{array}$ & $\begin{array}{l}\text { Personally } \\
\text { Pre-registration }\end{array}$ \\
\hline 27 & Ondokuz Mayis U. & 40 & $\begin{array}{l}\text { 23rd Jul } \\
\text { August }\end{array}$ & $\begin{array}{l}y-12 \text { th } \\
018\end{array}$ & $\begin{array}{l}\text { 14-15th } \\
\text { August } 2018\end{array}$ & Online Pre-registration \\
\hline 28 & Pamukkale U. & 40 & $\begin{array}{l}6-9 \text { th } \\
2018\end{array}$ & August & $\begin{array}{l}\text { 13th August } \\
2018\end{array}$ & Online Pre-registration \\
\hline 29 & Sivas Cumhuriyet U. & 35 & $\begin{array}{l}\text { 06-17th } \\
2018\end{array}$ & August & 5th Sept 2018 & $\begin{array}{l}\text { Personally } \\
\text { Pre-registration }\end{array}$ \\
\hline 30 & Tokat Gaziosmanpasa U. & 40 & $\begin{array}{l}1-29 \text { th } \\
2018\end{array}$ & August & 4th Sept.2018 & Online Pre-registration \\
\hline 31 & Trabzon U. & 50 & $\begin{array}{l}\text { 6-8th } \\
2018\end{array}$ & August & $\begin{array}{l}\text { 15-17th } \\
\text { August } 2018\end{array}$ & $\begin{array}{l}\text { Personally } \\
\text { Pre-registration }\end{array}$ \\
\hline 32 & Trakya U. & 35 & Not reac & & & \\
\hline 33 & Van Yuzuncu Yil U. & 40 & $\begin{array}{l}\text { 27th At } \\
\text { Sept. } 20\end{array}$ & $\begin{array}{l}\text { gust, }-5 \\
8\end{array}$ & $\begin{array}{l}\text { 10-11th } \\
\text { Sept.2018 }\end{array}$ & $\begin{array}{l}\text { Pre-registration in Person } \\
\text { and by Post }\end{array}$ \\
\hline 34 & $\begin{array}{l}\text { Yakin Dogu U. (KKTC) } \\
\text { TOTAL }\end{array}$ & $\begin{array}{l}30 \\
1550\end{array}$ & Not reac & & & \\
\hline
\end{tabular}

According to Table 2, 10 of the 23 universities get exam application with online pre-registration, 4 universities get both with online and personally apply for the exam, 6 universities with personally 2 universities personally and/ or by post. 
As the Special Talent Exam dates of the universities are taken into consideration, it is noticed that most of the exams are between the 3rd week of August and 1st week of September. As the Examination results of the Institutions of Higher Education in 2018 were declared on 31st July, it is clear that five weeks of a period is used for the application and exam date. As it is understood from the table, it is believed that earlier declaring the HIE exam results will extend the date and exam range, this case will provide ease in practice. Exam application and shortening the exam period to 1 month means to the concentration of the applications in most of the universities, that the applications of some universities not reaching to the desired number. It cannot be possible to make the HIE exams earlier, but the announcement of the results within 20 days will give an additional 10 days for the institutions that will make special talent exams. The fact that the months, in which special talent exams are held, coincide with the summer months, in which the instructors employed in higher education institutions use their annual leave, increases the limitations in terms of the dates of the special talent exams. One of the reasons why some universities did not fill their quota in 2018 may be due to short application and exam date range. Besides, there is period as 1 week and 2 weeks between exam application dates and exam dates and it necessitates the candidates to travel to the province of the Higher Education Institution twice in approximately 10 days. Exam experiences have shown that particularly families with financial difficulties refrain from sending their candidates both to the application and to the exam twice for the exams, which require application in person. In that case, it will be appropriate for the institutions, which take applications in person, to make their exams one day after the application deadline. It can be easier for the ASPC to take the applications for the Special Talent Exam online as the documents required from the candidates are available in the ASPC candidate transactions system. Besides, centralized examinations will be the solution to the problems encountered in this case.

3.2 What Are the Application Conditions of the Special Talent Exams for Art Teaching Divisions of Fine Arts Departments of Education Faculties?

Findings related to the application conditions of the Special Talent Exams for Art Teaching Divisions of Fine Arts Departments of Education Faculties are presented in Table 3.

Table 3. 2018 HIE Art Teaching Programs and Quotas

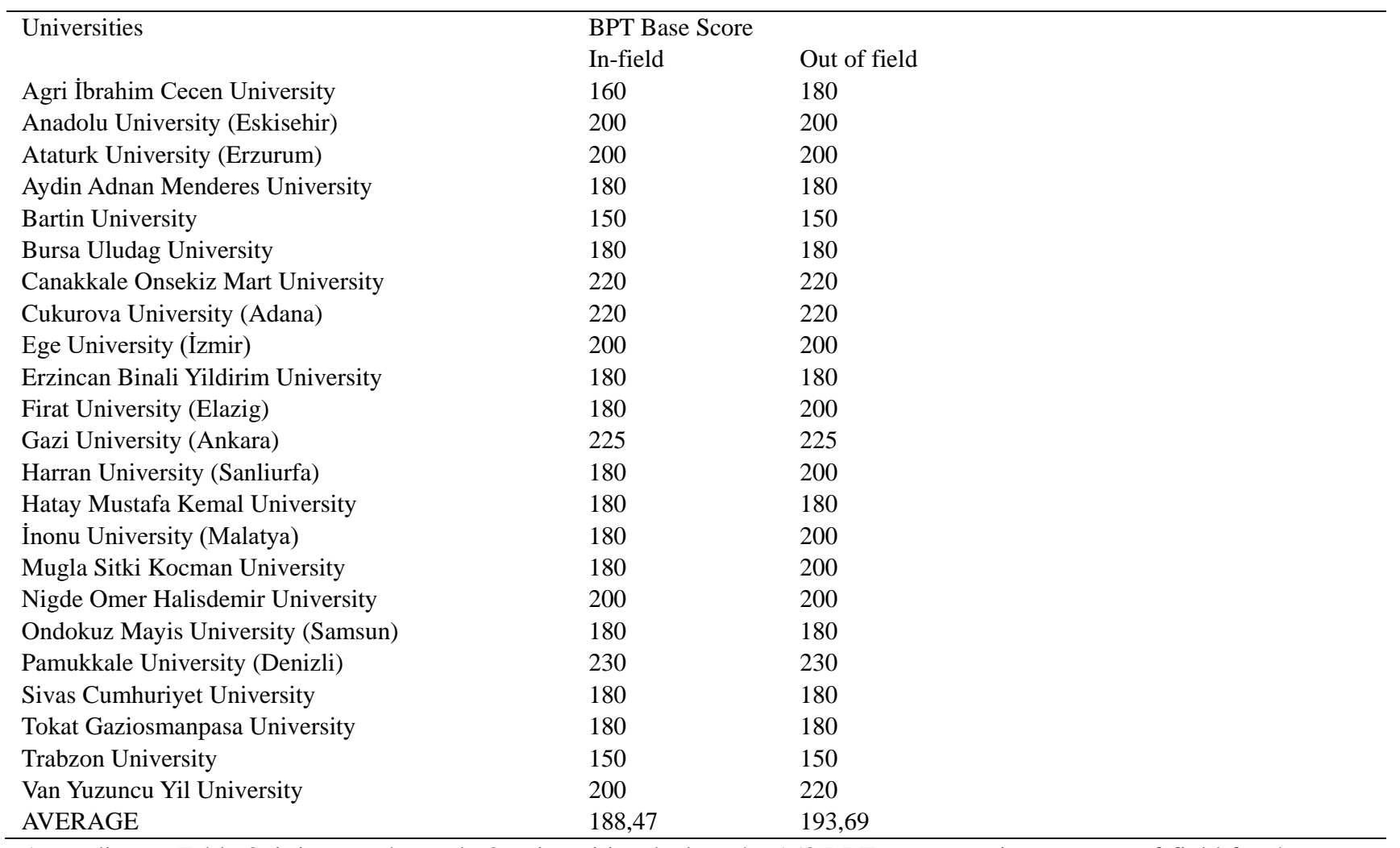

According to Table 3, it is seen that only 2 universities declare the 150 BPT score requirement out-of-field for the exam application; 8 universities 180 BPT score out-of-field; 8 universities 200 BPT out-of-field; 3 universities 220 BPT score out-of-field; 1 university 225 BPT score out-of-field, 1 university 230 BPT score out-of-field. On the other hand, it is indicated in the Table that 1 university requires 160 score in-field; 11 universities 180 score in-field; 5 universities 200 score in-field, 2 universities 220 score in-field; 1 university 225 score in-field; 1 university 230 score in-field. As it is understood from the Table 3, the base score, 150 BPT, which is required by the universities for ASPC in special talent 
exams, is adopted by 2 universities, generally, 180 and 200 BPT scores are adopted as the base scores. The programs requiring Special Talent Exam in the manual of the ASPC (2018) are presented in To apply the Higher Education Programs stated in the HIE 2019 manual, it is expressed that "the 2018-BPT score has to be at least 150. The relevant higher education institution will decide on the applicants who have received at least few points for these programs and will be announced to the candidates by the relevant higher education institution via press and media organs." According to this decision, it is seen that most of the 23 universities preferred the scores between 180 and 200. The decision of the ASPC stating in the ASPC 2018 HIE manual that the 300,000-success ranking brought by the faculties of education to AYT (Field Proficiency Exam) to undergraduate programs that will take students for Special Talent Exam will be applied as of 2019, indicates that the BPT placement scores will increase. In the 2018 HIE evaluation report, as that the BPT score which corresponds 300.000 success ranking was approximately 273,5 BPT score (ASPC, 2018) is taken into consideration, it is understood that the scored determined by the Institutions of Higher Education is not too high. In addition, in the decision letter sent by the Higher Education Council to higher education institutions, in the Higher Education General Assembly meeting dated 30th May, 2019, it was referred that "It was decided that in the programs where the number of students enrolled as a result of HIE 2018 is less than the quota, the higher education institutions to make transactions according to BPT base score 150 and above, the mentioned score cannot be raised by the relevant boards of higher education institutions and the announcements for the base score and other required essentials will be sent to the Higher Education Council". The implementation of the 300000 BPT success ranking also endangers the existence of fine arts high schools. With the decision in 30th March 2012, the additional points will be considered for the students, who have graduated from high school institutions and apply a program for a profession as of 30th March 2012; or who are studying before and on the specified date, not for the applicants, who have registered to the relevant education institution after 30th March 2012. And this decision has greatly reduced the probability of candidates from fine arts high schools to be successful in the field. In the current situation, it can be said that the 300000 success ranking brought to the faculties of education cannot be an application requirement for special talent exams. Instead, 180 BPT score requirement for 4-year faculty preference can be considered sufficient for the application requirement.

3.3 What Are the Steps of the Special Talent Exams for Art Teaching Divisions of Fine Arts Departments of Education Faculties?

Findings related to the steps and achievement criteria of the Special Talent Exams for Art Teaching Divisions of Fine Arts Departments of Education Faculties are presented in Table 4.

Table 4. Findings related to the Exam Type and Achievement Requirements of the Special Talent Exams Manuals for the 2018 Art Teaching Divisions

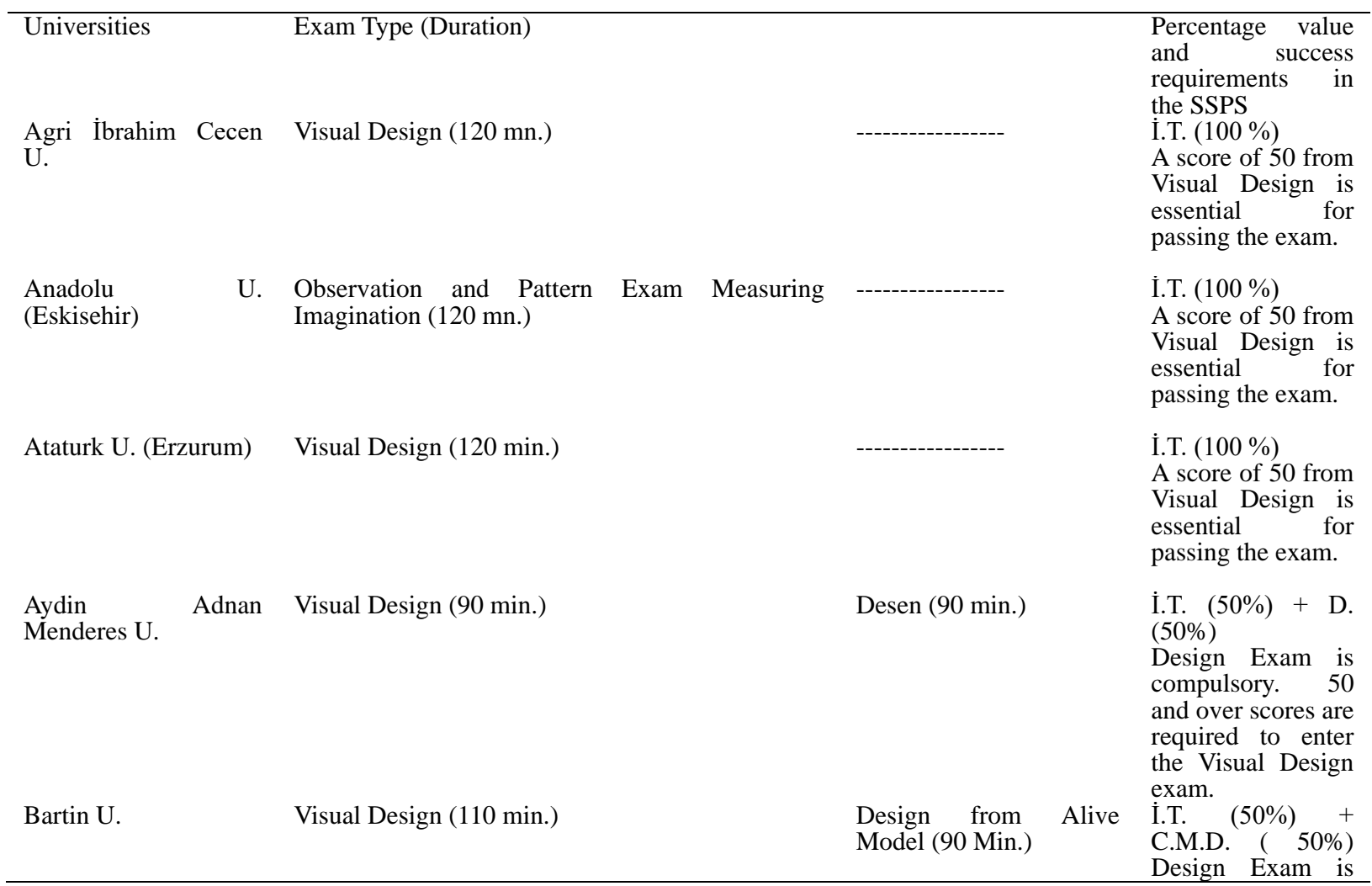


Bursa Uludag U. Design From Memory

Canakkale Onsekiz Design from Model (100 min.) Mart U.

Cukurova U. (Adana)

Ege U. (İzmir)

Design Exam (120 min.)

Design Exam (90 min.) Erzincan Binali Design from Alive Model (90 min.)
Yildirim U.

Firat U. (Elazig)

Visual Design (100 min.)

Gazi U. (Ankara)

Harran U. (Sanliurfa)

Hatay Mustafa Kemal U.

İnonu U. (Malatya)
Design from Alive Model (90 Min.)

Design from Alive Model (90 Min.)

Design from Model

Design from Model
Design from Alive Model/ alive model and interpretation/observatio n-based design/ one of the observation-based design and interpretation

Visual Design (120 min.)

Design

(1)

compulsory. 50

and over scores are required to enter the Visual Design exam. Also, a score of 50 from Visual Design is essential for passing the exam.

B.D. $(50 \%)+$ D. $(50 \%)$

Design Exam from Memory is compulsory. $\quad 50$ and over scores are required to enter the 2nd stage exam.

I.T. $(50 \%)+$ M.D. $(50 \%)$

Design Exam is compulsory. $\quad 50$ and over scores are required to enter the Visual Design exam. D $(100 \%)$

Visual Design (90 min.) İ.T. (50\%) + M.D. (50\%) Design Exam is compulsory. $\quad 60$ and over scores are required to enter the Visual Design exam.

Visual Design (90 min.) İ.T. $(50 \%) \quad+$ C.M.D. $(50 \%)$

50 score from both exams is essential to calculate the STES score of candidates.

Design from Alive İ.T. (50\%) + Model (90 Min.) C.M.D. (50\%)

Visual Design Exam is compulsory. $\quad 50$ and over scores are required to enter the Visual Design exam.

Visual Design (90 min.) C.M.D. (50\%) + I.T. $(50 \%)$

Those whose average is below 49.5 scores will not be evaluated.

Visual Design (90 min.) C.M.D. (50\%) + İ.T. $(50 \%)$

Those whose average is below 50 scores will not be evaluated.

İ.T. $(50 \%)+$ M.D. $(50 \%)$

Design Exam is compulsory. $\quad 50$ and over scores are required to enter the Visual Design exam

C.M.D. $(\% 50)+\dot{I} . T$.

(\% 50)

Those whose 


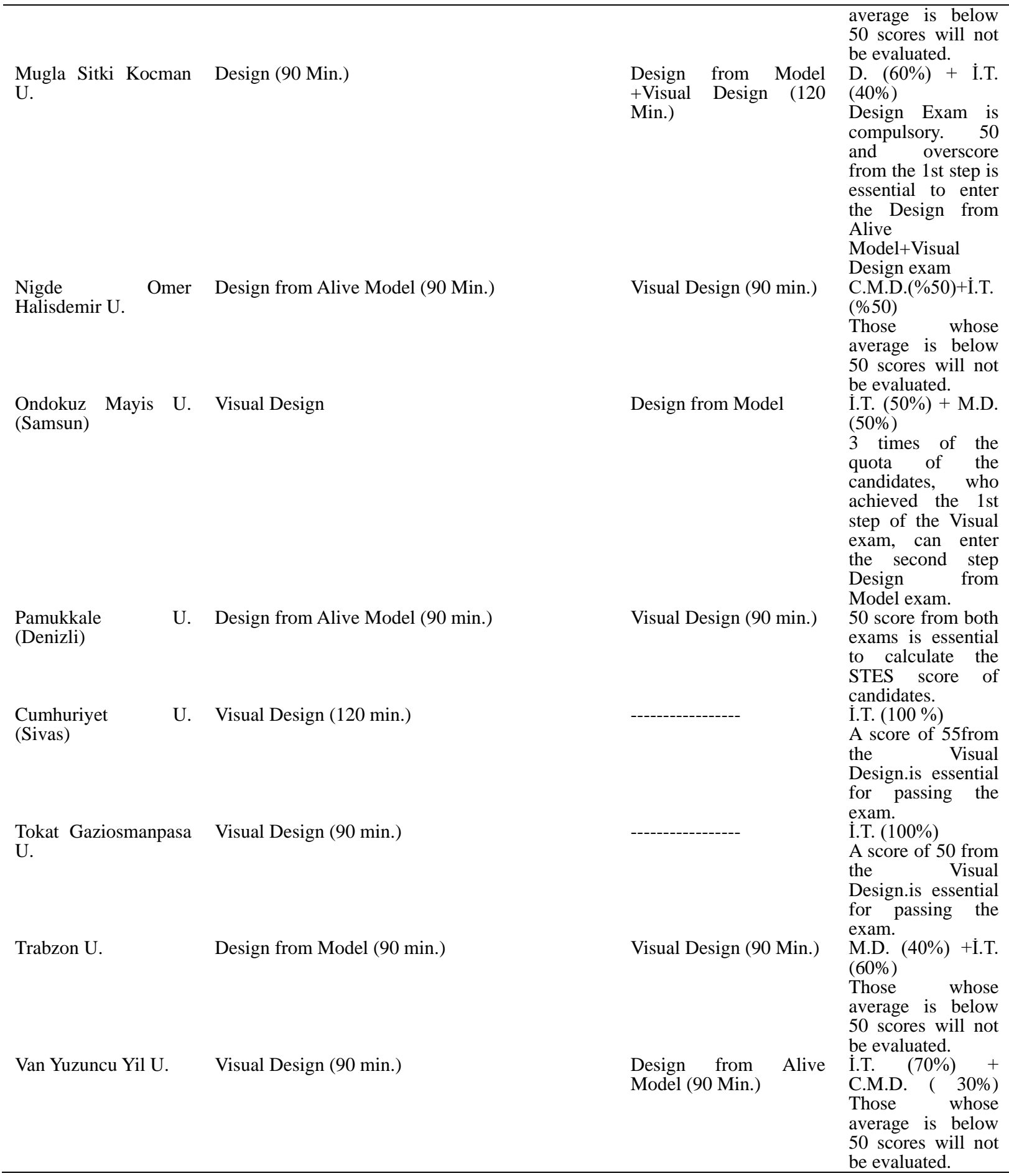

As Table 4 is analysed, it is realised that the exam types of the higher education institutions are similar in general (Design from Model, Visual Design), some of the institutions prefer only one of the criteria, specifically the Visual Design exam type. In almost all the exams, it is seen that $90 \mathrm{~min}$. of duration is applied. Also, except for some examples (Trabzon U., Van Yuzuncu Yil U.) 50\% and 50\% weighted calculation is applied in the evaluation of Design and Visual exam types. It is thought that mostly two steps of exam types are applied and it is reasonable as the power of design and visual design in art training is taken into consideration. The base score as 50, applied in the evaluation of the exam, is also applied in election exam by some institutions and in the average of SSPS for most of the institutions. In very few institutions, (Pamukkale U., Erzincan Binali Yildirim U., Bartin U.) it is encountered to be applied in both steps. As can be seen from Table 4, considering the findings of the research, it is seen that mostly the higher education institutions make an exam including two stages and one of these exams is Alive and Lifeless Model Drawing, the other is Visual Design. In the evaluation of almost all exams, the step weights are half-and-half. Besides, its average constitutes the 
SSPS (Special Talent Exam Score). In constituting the Special Talent Exam score, some higher education institutions declare the requirement of 50 scores for each stage and others require for average. This requirement prevents students who do not have special talents but who have a high BPT score from passing the exam. It is seen that the criteria used in the evaluation such as the use of space usage (placement), ratio-proportion, perspective, motion-balance, linear values, light-shadow, creativity-observation power, suitability to the subject are used as common evaluation criteria. Although the exam types, evaluation criteria and the lowest scores that are applied by the higher education institutions for determining the Special Talent Exam score seem to be close to each other, ASPC's determination of the implementation and evaluation criteria of this exam will provide a more objective exam in terms of unity.

\subsection{What Criteria Are Used in the Evaluation of the Special Talent Exams for Art Teaching Divisions of Fine Arts Departments of Education Faculties?}

As he criteria applied in the evaluations are taken into consideration, generally, the use of space (placement), ratio-proportion- anatomy-perspective, motion-balance, linear value, light- shadow are applied from the design exam. In visual exam type, it is noticed that the creativity, originality, mastery of the subject, composition, movement, ratio-proportion, linear expression, visual-perception skills, observation power. As the criteria applied in the exam types are the features that should be included in the design and Visual Design works by the experts in the field, it is believed that there is no need to discuss this issue where these criteria are appropriate to use.

\section{Discussion and Result}

Within the Transition to Higher Education exams, Special Talent Exam has been applied as a model for a long time. Gurbuzturk \& Kincal (2018) refer that selecting students to the Higher Education institutions, apart from the central placement, has also been actualised with the Special Talent exams dating back to 1975. It is expected that an exam with a history of nearly half a century will be carried out in the best way with the knowledge, qualification and experience. However, as it is understood from several pieces of research, it is not easy to measure and evaluate individuals with special talents. "Many students with different expectations apply to the faculties taking the students with special talent exam. Student selection for these departments, which are very few, is very difficult. Because a large number of candidates apply for a limited number of quotas. Among these students, the most talented ones in terms of art education and the ones that can be developed should be selected. This brings many difficulties" (Altinkurt, 2006, p. 228). Artut (2001) referred in his research that the measurement and evaluation process in art education in art education is extremely difficult (p.293). It can be claimed that there are several reasons originated from the application and evaluation requirements related to the Special Talent Exam (Kavuran, 2004, p. 170). In the application and evaluation processes of the special talent exams, several measurements and evaluation difficulties related to the exam were reported and the exam was turned into the current application, implementation, measurement and evaluation form.

In its current form, the application conditions of the exam (except that the Basic Proficiency Exam Score should not be less than 150 points) (ASPC, 2019), implementation and constitution of Special Talent Exam Scores were given to the right of the Higher Education Institutions. Although the application conditions, the implementation of the exam and the constitutions of special talent scores show some similarities by the Higher Education institutions, there are also some differences. Although no study will provide a discussion of the findings of the research aiming to determine these differences, the answers to the questions of the research have been tried to be discussed and interpreted in the light of the existing researches (Ucan 1995; Kavuran, 2004; Altinkurt, 2006; Askin Kumova \& Demirbatir, 2012; Arapgirlioglu \& Tankiz, 2013; Sager \& dig.2015; Karadag, 2016; Atilgan, 2018) on the subject. The findings obtained in the context of the first question of the study show that the majority of higher education institutions require an application for exams with online pre-registration. An online application is the easiest type of application for candidates from different provinces. However, the problem of questioning the authenticity of the points and documents used in the on-line application constitutes the disadvantages of this application model. To overcome these disadvantages, most Higher Education Institutions have also applied to apply for exams in person after online pre-registration. Few institutions consider receiving the application in person as the most appropriate application form. A few institutions receive applications by post. To increase the chances of candidates wishing to transfer to higher education with special talents, desiring to take more than one exam makes it compulsory to travel to the provinces where the universities requiring application in person or both on-line and in person. This sort of application brings a burden on family budgets, considering road fare, accommodation and other expenses. Also, the fact that there is a time difference between application dates and exam dates can be interpreted as increasing this burden. When the application and exam dates are considered, it is seen that almost all institutions have a week between the application date and the exam date. This means that candidates have to travel twice with the institution for both application and examination. In this context, the Central Special Talent Exam (MOZYES) in 1994, 1995 and 1996 can be regarded as the solution to this problem. "The system of selecting students with the MOZYES (Central Special Talent Exam), started to be applied even in the field of art with the cooperation of the ASPC has the qualification to consist of the Fine Art Faculties. This new formation raises 
a new structure or arrangement in the selection and placement of students in art faculties" (Ucan, 1995, p. 133. Especially because the declaration of the HIE exam results reaching to the end of July after 2018 brought the necessity to make the Special Talent Exams in one month for all the institutions, it has become difficult to make more than one Special Talent Exam application and attend the exams. MOZYES exams can be shown as a solution to the congestion of exam dates.

According to the findings of the research related to the application conditions, very few higher education institutions applied 150 BPT base score put into the manual by the ASPC. The higher education institutions generally accepted the 180 BPT score as a condition for exam application. Some institutions have placed a base score requirements for candidates coming from the field, while a higher score is required for non-field candidates. In the research conducted by Altinkurt in 2006 for a higher education class, it was found that $85,7 \%$ of the candidates had taken scores between 170-210 in OSS with the previous name of the exam. The finding in this research shows that 180 score is the appropriate base score for this exam. Besides, the average score of the 23 higher education institutions, which are the sample for the research, is 188 proves that 180 score is appropriate. Although that the application of the score requirement is applied differently for the candidates applied in field and out-of-field is considered as positive discrimination for the candidates coming from the field, it is evaluated that it may harm the principle of equality in exams. Although Altinkurt (2006) recommends in the research that the OSS (BPT in 2018) base score can be increased during the application of the special talent exams, but the OSS score should not be taken into consideration in the evaluation of the special talent exam, actually it will be appropriate to apply the BPT score for the programs of faculties of education that require talent.

Also, it should not be forgotten that 300000 success ranking requirement is applied for all the departments of faculties of education and success ranking will be applied for the special talent exams. In terms of the 2018 scores, it is thought that the application of 300000 success rankings for special talent exams, corresponding to approximately 273 points, will reduce the application of the exam to numbers that cannot fill the quota. Instead of reducing the base score, reducing the quotas is considered more accurate.

Another finding of the research is related to the exam type applied in the Special Talent Exam by the higher education institutions. It is seen that the exam types used in the higher education institutions are design from alive and lifeless model and visual design, some institutions prefer only one of these - generally the visual design exam type- 90 minutes of duration is applied in almost all of the exams, 50\% and 50\% weight is given to the evaluation of pattern and visual design exams. Some researches put forth that these applied exams are memorised in the courses before the exams, so a correct measurement cannot be done. Altinkurt (2006) claimed that the person and institutions that educate students for the special talent exam, memorize certain postures to students, especially in pattern drawing the students' instant performance in one or two days of exams held in can be misleading, many problems, such as assessment criteria, make the selection process difficult. (p.228). According to Yolcu (2004, p.153), students made the drawings by memorizing some model postures. in talent exam preparation courses, support this opinion. Besides, there are findings related to that one-third of the candidates failed the pattern exam and two-thirds failed the visual design exam (Altinkurt, 2006, p. 233). The finding supports the previously mentioned memorized posture thesis. Because, in the first exam, especially the pattern drawing from the alive model is applied with similar model postures. Candidates may memorize these similar positions in the courses. In the second exam, the imaginary exam, it is normal to see an increase in failure when the subjects vary according to the institutions. In addition to the Special Talent Exam score, the use of BPT score and the SEAS (Secondary Education Achievement Score) for placement score is another finding that is noteworthy among the research findings. According to some researches (Arapgirlioglu \& Tankiz,2013; Gokbulut, 2004), it was noticed that the SSPS had 35\% weight, HETS, which was the name of the exam during the research period, had $40 \%$ weight and the SEAS had $25 \%$. Besides that these ratios were reasonable for the art teaching departments, perhaps the higher rate of talent exam may be more appropriate for the faculties of fine arts and conservatories. Furthermore, as it is referred in the recommendations of Arapgirlioglu \& Tankiz (2013), it is clear that it will be appropriate to determine the most suitable form by establishing a commission within the body of YOK by selecting representatives from each university that takes students through special talent exam.

Consequently, it is understood in the research, on-line registration provides some advantages; however, enabling the date for the exam registration up to the day before the exam can provide the applicants the travel and accommodation facilities. There is a consensus that the BPT score, which is determined as an application condition, being within the range of 180-200 points, the scores to be determined above these scores will cause the quotas to remain empty. On the other hand, a consensus was reached in terms of exam type duration and evaluation criteria. Also, in terms of unity in implementation of the exam, it is thought as the most appropriate method that the Central Special Talent Exams should be held by ASPC. 


\section{References}

Altinkurt, L. (2006). Universitelerdeki guzel sanatlar egitim programlari giris sinavi sonuclarinin degerlendirilmesi. (Dumlupinar Universitesi Guzel Sanatlar Fakultesi Ornegi), Evaluation of Results of Fine Arts Education Programs Entrance Exam at Universities (Sample of Dumlupinar University Fine Arts Faculty). Dumlupinar Univeritesi Sosyal Bilimler Dergisi, 15, 227-238.

Arapgirlioglu, H., \& Tankiz, K. D. (2013). Ozel yetenek sinavlarinda AOBP ve YGS puanlarinin yerlestirme puanlari icerisindeki dagiliminin incelenmesi (Examining of the Distribution of AOBP and YGS Scores in Placement Scores in Special Ability Exams). Hacettepe Universitesi Egitim Fakultesi Dergisi, 28(2), 14-26.

Artut, K. (2001). Sanat egitimi kuramlari ve yontemleri (theories and methods of art education). İstanbul: Ani Yayincilik.

Artut, K. (2004). Sanat egitimi (Art Education). Ankara: Ani Yayincilik

Askin, K. P., \& Demirbatir, R., E. (2012). Muzik ogretmenligi programlari kapsaminda ozel yetenek sinavlarinin karsilastirilarak incelenmesi (Analysis of Compared Music Ability Exams in Music Teachers' Education Programs), GEFAD / GUJGEF 32(1), 103-127.

ASPC (2018a). 2018-Yuksekogretim Programlari ve Kontenjanlari Kilavuzu. Retrieved from https://dokuman.ASPC.gov.tr/pdfdokuman/2018/HIE/KONTKILAVUZ6082018.pdf

ASPC (2018b). 2018-Yuksekogretim Kurumlari Sinavi (HIE) Kilavuzu. Retrieved from https://dokuman.ASPC.gov.tr/pdfdokuman/2018/HIE/KILAVUZ_28062018.pdf

ASPC (2018c). 2018-Yuksekogretim Kurumlari Sinavi (HIE) (Raporu. examination of higher education institutions Report). Retrieved from https://dokuman.ASPC.gov.tr/pdfdokuman/2018/GENEL/HIEDegrapor06082018.pdf

At1lgan, H. (2018). Turkiye'de kademeler arasi gecis: dunu-bugunu ve bir model onerisi (Transition among Education Levels in Turkey: Past-Present and a Recommended Model). Ege Egitim Dergisi / Ege Journal of Education, 19(1), 1-18. https://doi.org/10.12984/egeefd.363268

Duverger, M. (1973). Sosyal bilimlere giris: metodoloji acisindan (Cev) Unsal Oskay. Ankara: Bilgi

Erol, S. E. (2016). Ustun yetenekli ogrencilerin sanat alaninda degerlendirmesinde dunya genelinde kullanilan yontemler. Hasan Ali Yucel Egitim Fakultesi Dergisi, 13(1), 85-93.

Gokbulut, N. (2004). Ataturk universitesi Kazim Karabekir-Agri-Erzincan egitim fakulteleri guzel sanatlar egitimi bolumleri, resim-is ve muzik egitimi anabilim dali orneginde ozel yetenek sinavi puanlarinin degerlendirilmesi. Gazi Universitesi Sanat Egitimi Sempozyumu, Ankara: Gunduz Egitim ve Yayincilik

Gurbuzturk, O., \& Kincal, R. Y. (2018). Turkiye'de yuksekogretime gecis surecinin analizi: gelismeler, modeller ve uygulamalar (The Analysis of The Transition Process to Higher Education: Improvements, Models and Applications). Akdeniz Egitim Arastirmalari Dergisi, 12(24), 33-54. https://doi.org/10.29329/mjer.2018.147.3

Karadag, F. (2016). Ozel yetenekli bireylerin tanilanmasi ve tanilamaya yonelik alternatif Degerlendirme araclari. Uluslararasi Sosyal Arastirmalar Dergisi, 9(46). https://doi.org/10.17719/jisr.20164622623

Karasar, N. (2003). Bilimsel arastirma yontemi, Ankara: Nobel Yayinlari

Kavuran, T. (2003-2004). Resim-is ogretmenligi anabilim dallarina ozel yetenek sinavlari ile ogrenci alinirken karsilasilan sorunlar. Sosyal Bilimler Dergisi, 159-180.

Kirpik, F., \& Sirin, N. (2012). Resim-is ogretmenligi anabilim dallarinda yapilan ozel yetenek sinavlarina yonelik bir durum degerlendirmesi. IDIL, 1, 5. https://doi.org/10.7816/idil-01-05-21

Madge, J. (1965). The tools of science an analytical description of social science techniques, Anchor Books Doubleday and Comp.

Ozsoy, V. (2002). Sanat (resim) egitiminde muze ve okul isbirligi ve muzeye dayali bazi ogretim yontemleri. Milli Egitim Dergisi, 153-154, Retrieved from http://dhgm.meb.gov.tr/yayimlar/dergiler/Milli_Egitim_Dergisi/153-154/ozsoy.htm

Sager, T., Zahal, O., Ozhan, U., \& Gurpinar, E. (2015). Ozel yetenek sinavina giren adaylarin ogrenme yollari ile sinav basarisi ve yerlestirmeye esas olan puanlari arasindaki iliskiler. VI. Uluslarasi Turkiye Egitim Arastirmalari Kongresi, Ankara. https://doi.org/10.9761/JASSS3124

San, İ. (1983). Sanat egitimi kuramlari (Theories of art education). Ankara: Tan. https://doi.org/10.1501/Egifak_0000000828 
Tepecik, A. (2002a). Grafik sanatlar tarih, tasarim, teknoloji ( Fine Artshistory, design, technology). Ankara: Detay.

Ucan, A. (1995). Turkiye'de guzel sanatlar fakultelerinin yeniden planlanmasi ve egitim programlarinin yeniden duzenlenmesi, Anadolu Universitesi G.S.F. sempozyumu 15-17 Mayis

YOK (2019). 30.05.2019 tarihli Yuksekogretim Genel Kurul toplantiKarar Metni (Higher Education General Assembly meeting decision text. Retrieved from

https://www.anadolu.edu.tr/uploads/anadolu/ckfinder/web/files/egitim-fakultesi-ozel-yetenek-sinavi-takvimi-ve-ko sullari.pdf

Yolcu, E. (2004). Ozel yetenek sinavlarinin resim yetenegini olcmedeki niteligi. Gazi Universitesi Sanat Egitimi Sempozyumu, Ankara: Gunduz Egitim ve Yayincilik.

\section{Copyrights}

Copyright for this article is retained by the author(s), with first publication rights granted to the journal.

This is an open-access article distributed under the terms and conditions of the Creative Commons Attribution license which permits unrestricted use, distribution, and reproduction in any medium, provided the original work is properly cited. 